Karolina KosSAKOWSKA

ORCID 0000-0003-3618-1918

MAGDALENA ZADWORNA

ORCID 0000-0002-0585-019X

Uniwersytet Łódzki

\title{
WYBRANE ASPEKTY \\ DOBROSTANU PSYCHICZNEGO UCZNIÓW NA RÓŻNYCH ETAPACH EDUKACJI. DONIESIENIA WSTĘPNE
}

\begin{abstract}
AвstRact. Kossakowska Karolina, Zadworna Magdalena, Wybrane aspekty dobrostanu psychicznego uczniów na różnych etapach edukacji. Doniesienia wstępne [Selected Aspects of the Psychological Well-Being of Students at Different Stages of Education. Preliminary Report]. Studia Edukacyjne nr 54, 2019, Poznań 2019, pp. 221-235. Adam Mickiewicz University Press. ISSN 1233-6688. DOI: 10.14746/ se.2019.54.13

Good mental health in childhood and adolescence is a prerequisite for optimal development, effective learning, build satisfying relationships with people, taking care of one's own physical health, and self-management in adult life. Psychological well-being means life satisfaction and covers various aspects of life: school, family, friends, hobbies, etc. Thus, the status of well-being among students is vital for their psychological functioning. The aim of the present study was to identify selected aspects of the mental well-being of students at different stages of education. Study participants included fifty-nine students aged between 12 and 19 years (both males and females). The participants filled out a questionnaire concerning various aspects of life satisfaction and social functioning, designed specifically for the study. The results show that girls are more satisfied from their lives than boys, but they assess their own's coping competencies lower than boys. Younger students show higher levels of general life satisfaction and better coping skills, although they more often have conflicting relationships with teachers. The results suggest that particular attention should be paid to older students, especially girls.
\end{abstract}

Key words: psychological well-being, adolescents, stages of education

\section{Wstęp}

Okres pomiędzy 10./12. a 18./20. rokiem życia określa się w psychologii rozwojowej mianem adolescencji (wieku dorastania). W czasie tym zauwa- 
żalne są intensywne zmiany fizyczne, związane z dojrzewaniem organizmu, które znacząco wpływają na inne sfery - poznawczą, społeczną i emocjonalną, moralną i sferę osobowości. Wzrasta zasób słownictwa, dokładność percepcji, myślenie staje się logiczne i przyjmuje postać operacji formalnych, rozwija się wyobraźnia ${ }^{1}$. Na okres ten przypada czas intensywnej nauki szkolnej - na różnych poziomach edukacyjnych (obecnie - gimnazjalnym i ponadgimnazjalnym). Rozwojowo zbiega się to także z podziałem na tak zwaną fazę adolescencji wczesnej (10. - 15. rok życia) oraz późnej (16. - 20. rok życia). Można zauważyć, że młodzież w różnych fazach adolescencji, a tym samym na różnych etapach edukacji funkcjonuje inaczej. Na przykład, kieruje się odmiennymi motywami i stylami zdobywania wiedzy ${ }^{2}$ czy stosuje zróżnicowane sposoby radzenia sobie ze stresem³ ${ }^{3}$.

Okres ten obfituje w liczne wyzwania. Zarówno przyspieszony, jak i opóźniony rozwój płciowy może być przyczyną problemów adolescentów. Fizjologiczne dojrzewanie organizmu wpływa na samoocenę - niektóre zmiany mogą być źródłem radości, inne dezaprobaty, dominują zaś uczucia ambiwalentne. Zwiększa się pobudliwość i labilność emocjonalna, częste są emocje lęku i zakłopotania. Zmienia się stosunek do rodziców, częściej dochodzi do konfliktów, a okres ten nie bez powodu nazywany jest czasem buntu. Na aktywność młodzieży wpływa istotnie środowisko szkolne, rodzinne i grupa rówieśnicza. Późna adolescencja to czas stabilizowania się zmian, kształtowania autonomii psychicznej i wkraczania w szersze życie społeczne. W pierwszej fazie adolescencji człowiek staje się dorosły pod względem fizycznym, zaś w okresie późnej adolescencji wkracza w dorosłość w sensie psychologicznym i społecznym ${ }^{4}$.

Przed jednostką stają wówczas konkretne zadania rozwojowe, typowe dla danego okresu życia. W okresie adolescencji należy do nich osiągnięcie nowych, bardziej dojrzałych więzi z rówieśnikami obojga płci, ukształtowanie roli męskiej lub kobiecej, akceptacja swojego wyglądu, osiągnięcie niezależności uczuciowej od rodziców i innych osób dorosłych, przygotowanie

${ }^{1}$ M. Kielar-Turska, Rozwój człowieka w petnym cyklu życia, [w:] Psychologia. Podręcznik akademicki, red. J. Strelau, Gdańsk 2003; I. Obuchowska, Adolescencja, [w:] Psychologia rozwoju człowieka. Charakterystyka okresów życia, red. B. Harwas-Napierała, J. Trempała, Warszawa 2004; A. Oleszkowicz, A. Senejko, Dorastanie [w:] Psychologia rozwoju człowieka, red. J. Trempała, Warszawa 2015.

${ }^{2}$ M. Zadworna-Cieślak, Sposoby i motywy zdobywania wiedzy przez uczniów szkót gimnazjalnych i ponadgimnazjalnych, [w:] Edukacja w zglobalizowanym świecie, red. V. Tanaś, W. Welskop, Łódź 2016.

${ }^{3}$ E. Pisula, R. Sikora, Wiek i płeć a radzenie sobie ze stresem przez młodzież w wieku 12-17 lat, Przegląd Psychologiczny, 2008, 4, s. 405-422.

${ }_{4}^{4}$ I. Obuchowska, Adolescencja; taże, Dorastanie - między moca a bezsilnościa, [w]: Zagrożenia okresu dorastania, red. Z. Izdebski, Zielona Góra 2012. 
do małżeństwa i życia w rodzinie oraz do kariery zawodowej, rozwijanie systemu wartości i postępowania odpowiedzialnego społecznie ${ }^{5}$. Poprzez realizację tych zadań jednostka formuje tożsamość osobową, czyli znajduje odpowiedź na pytanie „kim jestem”, oraz społeczną - określa, do jakiej należy grupy.

\section{Dobrostan psychiczny - ramy teoretyczne}

W kontekście burzliwych zmian rozwojowych ważną kwestią staje się jakość życia i zadowolenie z niego ${ }^{6}$ wśród adolescentów. Pojęcia takie, jak dobrostan psychiczny, szczęście, jakość życia, satysfakcja, czy zadowolenie z życia można uznać za bliskoznaczne. Zgodnie z koncepcją WHO, jakość życia to subiektywne postrzeganie przez jednostkę jej pozycji w życiu w relacji do jej celów, oczekiwań, standardów i zainteresowañ ${ }^{7}$. Powstała w latach dziewięćdziesiątych XX wieku nowa dziedzina psychologii - psychologia pozytywna zajęła się opisem i wyjaśnianiem tak zwanego dobrego życia, czyli życia o optymalnej jakości, dla którego przyjęto nazwę "dobrostan” (ang. well-being) nika między innymi z tego, że nie dla wszystkich ludzi dobre życie może oznaczać to samo. Za pomocne w związku z tym uznano odwołanie się do dwóch nurtów filozoficznych - hedonistycznego i eudajmonistycznego. Zgodnie z podejściem pierwszym, dobrostan jest pozytywnym stanem psychicznym przejawiającym się w wysokim poziomie satysfakcji z życia i jego różnych obszarów, przewadze uczuć pozytywnych nad negatywnymi oraz uogólnionym poczuciu szczęścia. Nurt eudajmonistyczny zaś koncentruje się na rozwoju, samorealizacji, zaangażowaniu ${ }^{9}$. Do tego ujęcia odnosić się będzie model opracowany przez Ryff ${ }^{10}$, składający się z takich aspektów, jak autonomia, poczucie posiadania celu w życiu, poczucie panowania nad oto-

${ }^{5}$ R. Havighurst, Developmental tasks and education, New York 1981.

${ }^{6}$ Ograniczone ramy niniejszego opracowania nie pozwalają na pełne rozważania terminologiczne, które zainteresowany Czytelnik znajdzie na przykład w tekście A. Dziurowicz-Kozłowskiej, Wokót pojęcia jakości życia, Psychologia Jakości Życia, 2002, 1(2), s. 77-99 lub J. Czapińskiego, Psychologia pozytywna, Warszawa 2004.

7 The WHOQOL Group, The World Health Organization Quality of Life Assessment (WHOQOL): Position Paper from the World Health Organization, Social Science and Medicine, 1995, 41(10), s. 1403-1409.

${ }^{8}$ L.A. King, J.E. Eells, C.M. Burton, Pojęcie dobrego życia - w ujęciu szerokim i waskim, [w:] Psychologia pozytywna w praktyce, red. P.A. Linley, S. Joseph, Warszawa 2007.

9 J. Czapiński, Psychologia pozytywna.

${ }^{10}$ C.D. Ryff, Happiness is everything, or is it? Explorations on the meaning of psychological well-being, Journal of Personality and Social Psychology, 1989, 57, s. 1069-81. 
czeniem, rozwój osobisty, pozytywne relacje z innymi ludźmi i samoakceptacja. Zdaniem Czapińskiego ${ }^{11}$, dobrostan psychiczny jest wieloaspektowy. "Cebulowa teoria szczęścia" stworzona przez autora wskazuje na jego trzy poziomy. Poziom najgłębszy to wola życia - obiektywny standard dobrostanu psychicznego jednostki - niezależny od świadomości, zdeterminowany genetycznie. Poziom pośredni to ogólny subiektywny dobrostan, który odpowiada poczuciu ogólnej satysfakcji i subiektywnie doświadczanej wartości własnego życia. Najbardziej zewnętrzną warstwę "cebuli szczęścia” stanowią bieżące doświadczenia afektywne oraz satysfakcje cząstkowe, odnoszące się do konkretnych aspektów życia (np. szkoły, rodziny). Z kolei Seligman ${ }^{12}$ proponuje opis tak zwanej „pełni życia”, składającej się z poczucia zaangażowania, pozytywnych emocji, sensu, osiągnięć i związków z innymi. Dobrostan w tym ujęciu można, a nawet trzeba, rozwijać. Seligman postuluje, jak sam pisze, „rewolucję w światowej edukacji”, czyli nauczanie umiejętności potrzebnych do podnoszenia dobrostanu, a więc tego, jak doświadczać więcej emocji pozytywnych, jak znajdować więcej sensu, tworzyć lepsze związki i więcej osiągać. Zdaniem autora, te idee powinny propagować szkoły na każdym poziomie edukacji.

\section{Dobrostan psychiczny polskiej młodzieży i jego wzmacnianie}

Przeprowadzone w Polsce na reprezentatywnej próbie uczniów w wieku 8, 10 i 12 lat badania subiektywnego dobrostanu wskazały na wysoki jego poziom $^{13}$. Najwyższe średnie wartości zadowolenia z życia obserwowano wśród 8-latków, najniższe wskaźniki zanotowano w grupie 12-latków, a poziom zadowolenia podobny był u reprezentantów obu płci. Najwyższe wskaźniki, we wszystkich kategoriach wiekowych, dotyczyły zadowolenia $\mathrm{z}$ życia rodzinnego, podczas gdy zadowolenie $\mathrm{z}$ funkcjonowania szkolnego było najniższe.

Podobnych wyników dostarczyły badania HBSC (Health Behaviour of School Aged Children), monitorujące stan zdrowia, dobrego samopoczucia, środowiska społecznego i zachowania zdrowia europejskiej młodzieży. Badanie przeprowadzone w Polsce w roku szkolnym 2013-2014 (tzw. HBSC 2014) obejmowało 4545 uczniów w trzech grupach, w których średni wiek wynosił

${ }^{11}$ J. Czapiński, Psychologia pozytywna.

${ }_{12}$ M. Seligman, Petnia życia, Poznań 2012.

${ }^{13}$ D. Strózik, T. Strózik, K. Szwarc, The subjective well-being of school children. The first findings from the children's worlds study in Poland, Child Indicators Research, 2016, 9(1), s. 39-50. 
odpowiednio 11,6, 13,6 i 15,6 lat. 33,6\% uczniów deklarowało bardzo wysoki poziom zadowolenia z życia, $47 \%$ - średnie, a co piąty nastolatek - niski. Średni wskaźnik satysfakcji z życia mierzony na skali 10-punktowej (tzw. drabina Cantrilla) wynosił 7,38 punktu $(S D=2,13)$. Badania HBSC ujawniły także różnicę między poczuciem życiowej satysfakcji dziewcząt i chłopców w wieku 11-18 lat. Niższe zadowolenie z życia deklarowały dziewczęta w porównaniu z chłopcami oraz starsza grupa wiekowa w porównaniu z młodszą $^{14}$. Na dobrostan psychiczny młodzieży wpływ miały: obraz siebie, relacje z rodzicami, nastroje i emocje, środowisko szkolne oraz niektóre czynniki społeczno-ekonomiczne ${ }^{15}$.

Mimo jednak relatywnie wysokiej satysfakcji z życia, polska młodzież przejawia wiele zachowań ryzykownych i niedostatki w zakresie wielu zachowań prozdrowotnych ${ }^{16}$. Ponadto, $\mathrm{w}$ porównaniu $\mathrm{z}$ innymi krajami europejskimi zajmuje niską pozycję $\mathrm{w}$ rankingu zadowolenia z życia, szczególnie w grupie 15-latków ${ }^{17}$.

Dobrostan psychiczny oraz zasoby osobiste leżące u jego podstaw można i należy wzmacniać. Na świecie prowadzone są profesjonalnie przygotowane szkolne programy prewencyjne dla młodzieży w kierunku zapobiegania depresji i wzmacniania dobrostanu psychicznego. Jednym z nich jest Penn Resilience Program, służący wzmacnianiu odporności psychicznej, rozwijaniu optymizmu, zapobiegający depresji i wzmacniający dobrostan ${ }^{18}$. Także $\mathrm{w}$ Polsce wzrasta liczba profesjonalnie przygotowanych programów profilaktycznych adresowanych do dzieci i młodzieży szkolnej ${ }^{19}$. Ważne jest oparcie proponowanych oddziaływań na rzetelnej teorii i wiedzy płynącej z badań empirycznych. Badania potwierdzają skuteczność tego typu oddziaływań dla wzmacniania dobrostanu, promowania zdrowia psychicznego i zmniejszania ryzyka depresji ${ }^{20}$.

${ }^{14}$ D. Zawadzka, Zadowolenie z życia, [w:] Zdrowie $i$ zachowania zdrowotne młodzieży szkolnej w Polsce na tle wybranych uwarunkowań socjodemograficznych. Wyniki badań HBSC 2014, red. J. Mazur, Warszawa 2015.

${ }^{15}$ J. Mazur i in., What does the Cantril Ladder measure in adolescence? Archives of Medical Science, 2016.

16 Tamże.

${ }^{17} \mathrm{~J}$. Inchley i in., Growing up unequal: gender and socioeconomic differences in young people's health and well-being, Health Behaviour in School-aged Children (HBSC) study: international report from the 2013/2014 SURVEY, 2016.

${ }^{18}$ K. Reivich, J. Gillham, Building Resilience in Youth: The Penn Resiliency Program, Communiqué, 2010, 38(6).

19 http:/ / www.programyrekomendowane.pl

${ }_{20}$ J.F. Young i in., A randomized depression prevention trial comparing interpersonal psychotherapy-adolescent skills training to group counseling in schools, Prevention Science, 2016, 17(3), s. 314324. 
Przykładem polskich działań służących opracowaniu programu promowania dobrostanu psychicznego uczniów w okresie wczesnej adolescencji jest 2-letni międzynarodowy projekt Well School Tech ${ }^{21}$, realizowany w ramach partnerstwa strategicznego programu Erasmus+. Program ten stał się inspiracją do przeprowadzenia wstępnych analiz dotyczących oceny przez młodzież szkolną swojego funkcjonowania w wybranych sferach życia (rówieśnicy, rodzina, szkoła).

\section{Cel badań}

Celem podjętych badań było określenie dobrostanu psychicznego młodzieży gimnazjalnej i licealnej. Badania miały charakter eksploracyjny, nie postawiono hipotez kierunkowych. Sprawdzano, czy etap edukacyjny i płeć w istotny sposób różnicują młodzież pod względem ogólnego zadowolenia z życia oraz wybranych aspektów funkcjonowania szkolnego i rodzinnego.

\section{Materiał i metoda}

W badaniu uczestniczyło łącznie 59 uczniów z województwa łódzkiego, w wieku od 12 do 19 lat $(M=16,07 ; S D=2,47)$. Grupa uczniów gimnazjum była równoważna pod względem płci uczestników (13 dziewcząt i 14 chłopców). W grupie uczniów liceum 62,5\% stanowiły dziewczęta (20 dziewcząt i 12 chłopców).

W badaniach wykorzystano ankietę własnego autorstwa, składającą się z dwóch części. Pierwsza część zawierała cztery twierdzenia odnoszące się do zadowolenia z wybranych aspektów życia (np. Jestem zadowolona/y z moich relacji z rówieśnikami), oceniane na 10-stopniowej skali, gdzie zaznaczenie

${ }^{21}$ Projekt edukacyjny Well School Tech (N. 2016-1-LT01-KA201-023171) jest realizowany na Wydziale Nauk o Wychowaniu Uniwersytetu Łódzkiego, w ramach partnerstwa strategicznego Erasmus+ od 2016 roku. W skład konsorcjum oprócz Uniwersytetu Łódzkiego wchodzą partnerzy z Litwy (Vilniaus Kolegija - koordynator projektu), Włoch (Promimpresa S.r.l oraz Instituto Superiore di Sanita), Bułgarii (European Center for Quality Ltd.) i Wielkiej Brytanii (Europa Training Ltd). W efekcie programu, który służy promowaniu dobrego samopoczucia psychicznego i jakości życia uczniów w okresie wczesnej adolescencji, mają powstać narzędzia pedagogiczne wspierające nauczycieli i wychowawców w radzeniu sobie ze złożonymi problemami wynikającymi z realiów szkolnych oraz $\mathrm{w}$ profilaktyce zachowań problemowych, poprzez włączenie do działań dla grupy docelowej takich interwencji, które pomogą i/lub poprawią zdolność definiowania celów osobistych, rozwiną umiejętność efektywnej komunikacji (w tym wyrażania pozytywnych i negatywnych emocji), a także wyposażą w umiejętność stosowania skutecznych strategii rozwiązywania problemów szkolnych i osobistych, w tym zarządzania gniewem, kontrolą emocji i reagowania na agresywne zachowanie (np. bullying). Istotną częścią projektu, realizowanego z wykorzystaniem metod ICT i podejścia partycypacyjnego, jest stworzenie na podstawie wybranych tzw. dobrych praktyk w zakresie kształtowania dobrostanu psychicznego multimedialnych narzędzi atrakcyjnych dla grupy docelowej projektu - młodzieży szkolnej (m.in. strona WWW, aplikacje, filmy). 
1 oznaczało „w bardzo małym stopniu”, a 10 - „w bardzo dużym stopniu”. Badani mogli uzyskać w tej części od 4 do 40 punktów. Wyższy wynik ogólny oznaczał większe ogólne zadowolenie z życia badanych osób. Na drugą część ankiety składało się siedem twierdzeń dotyczących oceny swojego funkcjonowania społecznego, w tym radzenia sobie w trudnych sytuacjach (np. Moge zawsze liczyć na pomoc moich rodziców; Kiedy dopada mnie stres umiem sobie z nim radzic). Badani oceniali, w jakim stopniu zgadzają się poszczególnymi twierdzeniami używając tej samej skali, gdzie wybór 1 oznaczał „całkowicie się nie zgadzam”, zaś 10 - „całkowicie się zgadzam”. Im wyższy wynik ogólny, tym lepszy deklarowany poziom funkcjonowania społecznego. Uczniowie mogli uzyskać w tej części od 7 do 70 punktów. Obliczono współczynniki rzetelności alfa Cronbacha dla każdej części ankiety, które okazały się zadowalające i wyniosły kolejno 0,69 i 0,77.

Do analizy statystycznej wykorzystano pakiet statystyczny PS IMAGO 24. Wykorzystując test Kołmogorowa-Smirnowa, sprawdzono normalność rozkładów dla zmiennych włączonych do analizy, to jest wyników ogólnych uzyskanych w obu częściach ankiety oraz wyników uzyskanych osobno dla każdego twierdzenia. Zastosowano statystyki opisowe, test t-Studenta oraz test U Manna-Whitneya $\mathrm{w}$ celu określenia różnic między grupami w zakresie wyników ogólnych oraz wyników uzyskanych dla poszczególnych twierdzeń ankiety. Przyjęty poziom prawdopodobieństwa wynosił $\alpha=0,05$.

\section{Wyniki}

\section{Rozkład wyników}

Obliczono wartości średnie dla zmiennych uwzględnionych $\mathrm{w}$ badaniu, to jest ogólnego poziomu zadowolenia, poziomu funkcjonowania społecznego oraz dla każdego twierdzenia zawartego w ankiecie.

Ogólne zadowolenie dla całej grupy ( $\mathrm{N}=59$ ) wyniosło średnio 27,37 punktów (SD =6,09; min. 13, max. 40), co przy rozpiętości od 4 do 40 punktów można uznać za wynik mieszczący się w środkowych wartościach skali. Podobnie, w przypadku ogólnego wyniku w zakresie funkcjonowania społecznego, który wyniósł średnio 45,66 punktów (SD = 11,04; min. 19, max.64), przy rozpiętości od 7 do 70 punków. Średnie dla poszczególnych twierdzeń zamieszczono $\mathrm{w}$ tabeli 1 . Wynika $\mathrm{z}$ niej, że najbardziej zgadzano się $\mathrm{z}$ twierdzeniem Rzadko popadam $w$ konflikty z nauczycielami, najmniej zaś z twierdzeniem Jestem zadowolony z mojej sytuacji w szkole. 
Średnie i odchylenia standardowe analizowanych zmiennych

\begin{tabular}{|l|c|c|c|c|}
\hline \multicolumn{1}{|c|}{ Zmienna } & M & SD & min & max \\
\hline Jestem ogólnie zadowolony z mojego życia & 6,61 & 1,92 & 2 & 10 \\
\hline Jestem zadowolony z mojej sytuacji w szkole & 6,19 & 1,87 & 2 & 10 \\
\hline Jestem zadowolony z mojej sytuacji rodzinnej & 7,27 & 2,58 & 1 & 10 \\
\hline Jestem zadowolony z moich relacji z rówieśnikami & 7,31 & 2,04 & 1 & 10 \\
\hline Zadowolenie - wynik ogólny & 27,37 & 6,09 & 13 & 40 \\
\hline \multicolumn{4}{|l|}{} \\
\hline $\begin{array}{l}\text { W moim otoczeniu są osoby, które wysłuchują mnie, kiedy } \\
\text { potrzebuję się wygadać }\end{array}$ & 7,07 & 2,47 & 1 & 10 \\
\hline $\begin{array}{l}\text { Umiem poradzić sobie z większością problemów, które } \\
\text { mnie spotykają }\end{array}$ & 6,97 & 2,25 & 1 & 10 \\
\hline Rzadko popadam w konflikty z nauczycielami & 7,42 & 2,63 & 1 & 10 \\
\hline Moi rówieśnicy akceptują mnie takiego, jaki jestem & 7,29 & 2,25 & 2 & 10 \\
\hline Mogę zawsze liczyć na pomoc moich rodziców & 7,42 & 2,60 & 1 & 10 \\
\hline Kiedy jestem w trudnej sytuacji, zazwyczaj wiem co robić & 6,73 & 2,16 & 1 & 10 \\
\hline Kiedy dopada mnie stres, umiem sobie z nim radzić & 6,61 & 2,63 & 1 & 10 \\
\hline Funkcjonowanie społeczne - wynik ogólny & 45,66 & 11,04 & 19 & 64 \\
\hline
\end{tabular}

\section{Etap szkoły}

Gimnazjaliści nie różnią się od licealistów pod względem ogólnego poziomu zadowolenia $\left(\mathrm{t}_{(57)}=0,963 ; \mathrm{p}=0,095\right)$, dostrzeżono jednak różnicę $\mathrm{w}$ ocenie funkcjonowania społecznego pomiędzy uczniami w zależności od etapu edukacyjnego $\left(\mathrm{t}_{(57)}=2,390 ; \mathrm{p}=0,020\right)$. Ocena ta jest wyższa wśród gimnazjalistów $(\mathrm{M}=49,26 ; \mathrm{SD}=12,07) \mathrm{w}$ porównaniu z licealistami $(\mathrm{M}=42,25 ; \mathrm{SD}=9,23)$. Porównanie średnich wyników uzyskanych $\mathrm{w}$ poszczególnych twierdzeniach ankiety dotyczących poziomu zadowolenia uczniów pokazuje istotne statystycznie różnice pomiędzy uczniami w zależności od etapu edukacyjnego w zakresie pierwszej i czwartej pozycji ankiety. Gimnazjaliści uzyskali wyższy od licealistów poziom zadowolenia ze swojego życia $(p<0,05)$ oraz ze swoich relacji z rówieśnikami $(p<0,05)$. Ponadto, gimnazjaliści deklarują w wyższym stopniu od licealistów umiejętność radzenia sobie ze stresem $(\mathrm{p}<0,05)$ i problemami, które ich spotykają $(\mathrm{p}<0,05)$, ale także $\mathrm{w}$ częstsze popadanie $w$ konflikty z nauczycielami $(\mathrm{p}<0,005)$. Dokładne wyniki zaprezentowano $\mathrm{w}$ tabeli 2. 
Tabela 2

Porównanie gimnazjalistów i licealistów pod względem średnich wyników uzyskanych w poszczególnych twierdzeniach ankiety

\begin{tabular}{|c|c|c|c|c|c|c|c|}
\hline \multirow[t]{2}{*}{ Lp. } & \multirow[t]{2}{*}{ Twierdzenie } & \multicolumn{2}{|c|}{$\begin{array}{l}\text { Gimnazjum } \\
(\mathrm{N}=27)\end{array}$} & \multicolumn{2}{|c|}{$\begin{array}{l}\text { Liceum } \\
(\mathrm{N}=32)\end{array}$} & \multicolumn{2}{|c|}{$\begin{array}{l}\text { Test } \\
\text { U Manna-Whit- } \\
\text { neya }\end{array}$} \\
\hline & & M & SD & M & SD & Z & $\mathrm{p}$ \\
\hline \multicolumn{8}{|c|}{ Poziom zadowolenia } \\
\hline 1 & $\begin{array}{l}\text { Jestem ogólnie zadowolony } \\
\text { z mojego życia }\end{array}$ & 7,19 & 2,02 & 6,13 & 1,72 & $-2,211$ & 0,027 \\
\hline 2 & $\begin{array}{l}\text { Jestem zadowolony z mojej } \\
\text { sytuacji w szkole }\end{array}$ & 6,30 & 1,98 & 6,09 & 1,80 & $-0,139$ & 0,889 \\
\hline 3 & $\begin{array}{l}\text { Jestem zadowolony z mojej } \\
\text { sytuacji rodzinnej }\end{array}$ & 7,48 & 2,55 & 7,09 & 2,63 & $-0,640$ & 0,522 \\
\hline 4 & $\begin{array}{l}\text { Jestem zadowolony z moich } \\
\text { relacji z rówieśnikami }\end{array}$ & 7,85 & 1,97 & 6,84 & 2,00 & $-2,068$ & 0,037 \\
\hline \multicolumn{8}{|c|}{ Funkcjonowanie społeczne } \\
\hline 5 & $\begin{array}{l}\text { W moim otoczeniu są osoby, } \\
\text { które wysłuchają mnie, kiedy } \\
\text { potrzebuję się wygadać }\end{array}$ & 7,41 & 2,66 & 6,78 & 2,30 & $-1,389$ & 0,165 \\
\hline 6 & $\begin{array}{l}\text { Umiem poradzić sobie z więk- } \\
\text { szością problemów, które } \\
\text { mnie spotykają }\end{array}$ & 7,67 & 2,22 & 6,38 & 2,14 & $-2,493$ & 0,013 \\
\hline 7 & $\begin{array}{l}\text { Rzadko popadam w konflikty } \\
\text { z nauczycielami }\end{array}$ & 6,15 & 2,90 & 8,50 & 1,80 & $-3,447$ & 0,001 \\
\hline 8 & $\begin{array}{l}\text { Moi rówieśnicy akceptują } \\
\text { mnie takiego, jaki jestem }\end{array}$ & 7,37 & 4,98 & 7,22 & 2,30 & $-0,200$ & 0,841 \\
\hline 9 & $\begin{array}{l}\text { Mogę zawsze liczyć na pomoc } \\
\text { moich rodziców }\end{array}$ & 7,56 & 2,55 & 7,31 & 2,68 & $-0,271$ & 0,786 \\
\hline 10 & $\begin{array}{l}\text { Kiedy jestem w trudnej sytu- } \\
\text { acji, zazwyczaj wiem co robić }\end{array}$ & 7,11 & 2,04 & 6,41 & 2,23 & $-1,149$ & 0,251 \\
\hline 11 & $\begin{array}{l}\text { Kiedy dopada mnie stres, } \\
\text { umiem sobie } \mathrm{z} \text { nim radzić }\end{array}$ & 7,30 & 2,61 & 6,03 & 2,55 & $-2,150$ & 0,032 \\
\hline
\end{tabular}

\section{Płeć}

Ogólny poziom zadowolenia jest wyższy wśród chłopców ( $\mathrm{M}=29,19$; $\mathrm{SD}=4,08) \mathrm{w}$ porównaniu $\mathrm{z}$ dziewczętami $(\mathrm{M}=25,94 ; \mathrm{SD}=7,03)\left(\mathrm{t}_{(57)}=-2,226\right.$; $\mathrm{p}=0,030)$. Chłopcy $(\mathrm{M}=49,00 ; \mathrm{SD}=9,91)$ wyżej od dziewcząt $(\mathrm{M}=43,03$; $\mathrm{SD}=11,32)$ oceniają też poziom funkcjonowania społecznego $\left(\mathrm{t}_{(57)}=-2,123\right.$; $\mathrm{p}=0,038)$. Analiza wyników uzyskanych dla poszczególnych twierdzeń ankiety wskazuje, że na podane wyżej różnice składa się przede wszystkim wynik dotyczący twierdzenia pierwszego - dziewczęta niżej od chłopców oceniają zadowolenie ze swojego życia $(\mathrm{p}<0,05)$. Ponadto, dziewczęta de- 
klarują, że w mniejszym stopniu niż chłopcy mogą liczyć na pomoc rodziców $(\mathrm{p}<0,05)$. W mniejszym stopniu niż chłopcy oceniają też swoją umiejętność radzenia sobie ze stresem, jest to jednak różnica na granicy istotności statystycznej $(p=0,056)$. Dokładne wyniki zaprezentowano w tabeli 3 .

Tabela 3

Porównanie dziewcząt i chłopców pod względem średnich wyników uzyskanych w poszczególnych twierdzeniach ankiety

\begin{tabular}{|c|c|c|c|c|c|c|c|}
\hline \multirow{2}{*}{ Lp. } & \multirow{2}{*}{ Twierdzenie } & \multicolumn{2}{|c|}{$\begin{array}{l}\text { Dziewczęta } \\
(\mathrm{N}=33)\end{array}$} & \multicolumn{2}{|c|}{$\begin{array}{l}\text { Chłopcy } \\
(\mathrm{N}=26)\end{array}$} & \multicolumn{2}{|c|}{$\begin{array}{l}\text { Test U Manna- } \\
\text {-Whitneya }\end{array}$} \\
\hline & & M & SD & M & SD & $\mathrm{Z}$ & $\mathrm{p}$ \\
\hline \multicolumn{8}{|c|}{ Poziom zadowolenia } \\
\hline 1 & $\begin{array}{l}\text { Jestem ogólnie zadowolony } \\
\text { z mojego życia }\end{array}$ & 6,03 & 2,07 & 7,35 & 1,44 & $-2,512$ & 0,012 \\
\hline 2 & $\begin{array}{l}\text { Jestem zadowolony } \mathrm{z} \text { mojej } \\
\text { sytuacji w szkole }\end{array}$ & 6,03 & 2,13 & 6,38 & 1,50 & $-0,542$ & 0,588 \\
\hline 3 & $\begin{array}{l}\text { Jestem zadowolony } \mathrm{z} \text { mojej } \\
\text { sytuacji rodzinnej }\end{array}$ & 6,73 & 3,10 & 7,96 & 1,59 & $-0,890$ & 0,374 \\
\hline 4 & $\begin{array}{l}\text { Jestem zadowolony } \mathrm{z} \text { moich } \\
\text { relacji z rówieśnikami }\end{array}$ & 7,15 & 2,11 & 7,50 & 1,96 & $-0,589$ & 0,556 \\
\hline \multicolumn{8}{|c|}{ Funkcjonowanie społeczne } \\
\hline 5 & $\begin{array}{l}\text { W moim otoczeniu są osoby, } \\
\text { które wysłuchają mnie, kiedy } \\
\text { potrzebuję się wygadać }\end{array}$ & 6,97 & 2,53 & 7,19 & 2,43 & $-0,379$ & 0,704 \\
\hline 6 & $\begin{array}{l}\text { Umiem poradzić sobie z więk- } \\
\text { szością problemów, które } \\
\text { mnie spotykają }\end{array}$ & 6,61 & 2,42 & 7,42 & 1,96 & $-1,305$ & 0,192 \\
\hline 7 & $\begin{array}{l}\text { Rzadko popadam w konflikty } \\
\text { z nauczycielami }\end{array}$ & 7,91 & 2,23 & 6,81 & 2,99 & $-1,376$ & 0,169 \\
\hline 8 & $\begin{array}{l}\text { Moi rówieśnicy akceptują } \\
\text { mnie takiego, jaki jestem }\end{array}$ & 7,24 & 2,36 & 7,35 & 2,15 & $-0,085$ & 0,932 \\
\hline 9 & $\begin{array}{l}\text { Mogę zawsze liczyć na pomoc } \\
\text { moich rodziców }\end{array}$ & 6,79 & 2,87 & 8,23 & 1,99 & $-2,278$ & 0,027 \\
\hline 10 & $\begin{array}{l}\text { Gdy jestem w trudnej sytuacji } \\
\text { zazwyczaj wiem co robić }\end{array}$ & 6,30 & 2,47 & 7,27 & 1,56 & $-1,207$ & 0,228 \\
\hline 11 & $\begin{array}{l}\text { Kiedy dopada mnie stres } \\
\text { umiem sobie } \mathrm{z} \text { nim radzić }\end{array}$ & 6,03 & 2,84 & 7,35 & 2,17 & $-1,952$ & 0,056 \\
\hline
\end{tabular}

\section{Wnioski}

W niniejszym artykule przedstawione zostały rezultaty wstępnego badania dotyczącego zadowolenia z życia i poziomu funkcjonowania wśród pol- 
skiej młodzieży szkolnej. Analiza wyników dla całej badanej populacji pokazuje, że uczniowie prezentują mieszczący się w średnich granicach poziom zadowolenia i funkcjonowania społecznego.

Podobne wnioski płyną z ogólnopolskich badań nastolatków, których generalnie można uznać za grupę raczej zadowoloną z życia ${ }^{22}$.

Warto jednak zwrócić uwagę, że pomimo deklaracji, że są akceptowani przez rówieśników, zadowoleni z relacji z nimi, czy też raczej rzadko popadają $\mathrm{w}$ konflikty $\mathrm{z}$ nauczycielami, to najniższe średnie wyniki uzyskali $\mathrm{w}$ twierdzeniu: jestem zadowolony ze swojej sytuacji w szkole. Sugeruje to potrzebę bardziej precyzyjnej eksploracji czynników związanych ze środowiskiem szkolnym, które mogą determinować poczucie satysfakcji z tej sfery życia $\mathrm{u}$ adolescentów. Jak bowiem wynika z innych badań, największym źródłem stresu dla młodzieży jest właśnie szkoła. Aż 70\% badanych nastolatków wymieniło ją jako przyczynę swoich największych problemów ${ }^{23}$. Szkoła wiąże się z wymaganiami, obciążeniem nauką i koniecznością bycia ocenianym, stresująca może być także atmosfera i relacje z nauczycielami. Wnioski te spójne są również z badaniami Strózik i współpracowników ${ }^{24}$, gdzie mimo relatywnie wysokiej satysfakcji z życia, najniższe zadowolenie dzieci i młodzieży dotyczyło sfery szkolnej.

Analiza uzyskanych wyników z uwzględnieniem podziału na etap edukacyjny (gimnazjum vs liceum) przyniosła informacje bardziej szczegółowe. Gimnazjaliści nie różnią się od swoich starszych kolegów i koleżanek w zakresie ogólnej oceny zadowolenia, jednak w odniesieniu do poszczególnych twierdzeń są najbardziej zadowoleni z życia i relacji z rówieśnikami. Takie rezultaty są spójne z wynikami uzyskanymi we wcześniejszych badaniach - im starsza młodzież, tym mniejsze zadowolenie z życia ${ }^{25}$. Na spadek satysfakcji z życia wraz z wiekiem wskazuje wiele innych badań prowadzonych $\mathrm{w}$ grupach dzieci i młodzieży ${ }^{26}$.

Uczniowie gimnazjum $\mathrm{w}$ większym stopniu niż licealiści deklarują posiadanie umiejętności radzenia sobie z dotykającymi ich problemami i stresem. Podobne wyniki uzyskano $\mathrm{w}$ badaniach odnośnie kondycji psychicznej nasto-

${ }^{22}$ D. Zawadzka, Zadowolenie z życia.

${ }^{23}$ R. Sikora, E. Pisula, Przyczyny stresu i strategie radzenia sobie ze stresem u młodzieży w wieku 14-16 lat, Polskie Forum Psychologiczne, 2002, 2, s. 110-122.

${ }^{24}$ D. Strózik, T. Strózik, K. Szwarc, The subjective well-being of school children, s. 39-50.

${ }^{25}$ D. Zawadzka, Zadowolenie z życia.

${ }^{26}$ F. Casas, Subjective social indicators and child and adolescent well-being, Child Indicators Research, 2011, 4(4), s. 555-575; C. Currie, C. Zanotti, A. Morgan, Social determinants of health and well-being among young people. Health Behaviour in School-Aged Children (HBSC) study: international report from the 2009/ 2010 survey, Copenhagen: World Health Organisation, 2012; H. Goswami, Children's subjective well-being: socio-demographic characteristics and personality, Child Indicators Research, 2014, 7, s. 119-140. 
latków, przeprowadzonych w 2014 roku wśród uczniów tarnowskich szkół gimnazjalnych i ponadgimnazjalnych ${ }^{27}$ - młodsi uczniowie lepiej radzili sobie z obowiązkami oraz związanymi z nimi problemami i stresem. Jednocześnie warto podkreślić, że gimnazjaliści w większym stopniu niż uczniowie na wyższym etapie edukacyjnym popadają $\mathrm{w}$ konflikty $\mathrm{z}$ nauczycielami. Jest to wynik ciekawy, zwłaszcza w kontekście ogólnego poziomu zadowolenia, który jest wyższy u młodszej młodzieży. Może to wynikać z rozwojowego zróżnicowania stosowanych strategii radzenia sobie ze stresem i sytuacjami trudnymi. Starsza młodzież bazując na osiągnięciach rozwojowych w sferze społecznej i intelektualnej, korzysta z różnorodnych strategii zaradczych, co może zmniejszać liczbę konfliktów interpersonalnych. Nie przekłada się to jednak na wzrost satysfakcji z życia. Potwierdzają to inne badania, w których młodzież starsza (16-17-letnia), częściej niż młodsza (12-13-letnia), koncentrowała się na problemie, a także częściej martwiła się ${ }^{28}$. Podobne wnioski przynoszą także inne badania ${ }^{29}$. Zróżnicowanie stosowanych strategii radzenia sobie można odnieść do sytuacji życiowej starszej młodzieży i rodzaju doświadczanych stresorów (np. zbliżająca się matura), z czym może wiązać się martwienie o przyszłość, ale też większa rozwaga w kontaktach z nauczycielami.

Analiza wyników z uwzględnieniem podziału na płeć również przynosi potwierdzenie wcześniejszych badań. Zadowolenie jest bowiem niższe $\mathrm{w}$ grupie dziewcząt i wyraża się przede wszystkim w różnicy poziomu zadowolenia z życia. Podobne różnice odnotowano w badaniach reprezentacyjnej próby polskich nastolatków w wieku 11-18 lat ${ }^{30}$. Nastoletnie dziewczęta mają także wyższe wskaźniki depresyjności niż chłopcy ${ }^{31}$. Należy jednak zauważyć optymistyczne wyniki badań, pokazujące, iż to z kolei dziewczęta w większym stopniu niż chłopcy podatne są na oddziaływania zwiększające poziom dobrostanu poprzez interwencje psychologiczne ${ }^{32}$.

Interesujący i skłaniający do dalszych poszukiwań jest wynik dotyczący wsparcia ze strony rodziców. Dziewczęta w mniejszym stopniu niż chłopcy zgadzają się z tym, że mogą liczyć na wsparcie ze strony rodziców. Istotne wydaje się sprawdzenie, czym uwarunkowana jest taka ocena ze strony na-

27 A. Latos, Kondycja psychiczna nastolatków. Raport z badań ankietowych przeprowadzonych w tarnowskich szkołach gimnazjalnych i ponadgimnazjalnych, 2014.

${ }^{28}$ E. Pisula, R. Sikora, Wiek i pteć a radzenie sobie ze stresem, s. 405-422.

${ }^{29} \mathrm{~K}$. Williams, A. McGillicuddy-De Lisi, Coping strategies in adolescents, Journal of Applied Developmental Psychology, 2000, 20, s. 537-549.

${ }^{30}$ D. Zawadzka0, Zadowolenie z życia.

${ }^{31}$ D. Gomez-Baya i in., A two-year longitudinal study of gender differences in responses to positive affect and depressive symptoms during middle adolescence, Journal of Adolescence, 2017, 56, s. 11-23.

${ }^{32}$ J.E. Gillham i in., Preventing depression among early adolescents in the primary care setting: A randomized controlled study of the Penn Resiliency Program, Journal of Abnormal Child Psychology, 2006, 34(2), s. 195-211. 
stolatek? Być może ma związek z przekonaniami oraz postawami rodziców dotyczącymi sposobów wychowania chłopców i dziewcząt, jak też wynikającymi z nich bardziej restrykcyjnymi oczekiwaniami właśnie wobec dziewcząt. Taka sytuacja może prowadzić u dziewcząt do przekonania, że w wielu okolicznościach nie mogą liczyć na rodzicielskie wsparcie. Na zróżnicowanie roli rodzicielskiego wsparcia w odniesieniu do aktywności młodzieży wskazują wyniki badań nad zachowaniami zdrowotnymi w tej grupie ${ }^{33}$. We wspomnianych badaniach zauważono także odmienną rolę wsparcia ze strony ojca i ze strony matki w zależności od płci nastolatka. Wskazane jest zatem w przyszłości badanie oceny wsparcia rodzicielskiego osobno ze strony matek i ojców.

Próbując z kolei zrozumieć, dlaczego dziewczęta niżej niż chłopcy oceniają swoje umiejętności radzenia sobie ze stresem, warto odwołać się do wspomnianych wcześniej badań Pisuli i Sikory ${ }^{34}$. Potwierdziły one, iż w zakresie niektórych strategii radzenia sobie, rozwój przebiega inaczej u dziewcząt i chłopców. Dziewczęta częściej niż chłopcy deklarowały stosowanie strategii polegających na poszukiwaniu wsparcia społecznego i przynależności, inwestowaniu w przyjaźń i poszukiwaniu wsparcia duchowego oraz radzeniu sobie przez wspólne działanie. Ponadto, częściej deklarowały koncentrację na problemie, pracy i osiągnięciach, relaksowanie się i martwienie. Różnice międzypłciowe w zakresie stosowanych strategii radzenia sobie ze stresem oraz różnych aspektów funkcjonowania potwierdza wiele badań ${ }^{35}$.

\section{Podsumowanie}

Przeprowadzone badania rysują obraz dobrostanu psychicznego adolescentów. Wskazały one na istotne różnice w zakresie zadowolenia z życia i funkcjonowania społecznego w zależności od etapu edukacji i płci. Ogólnie można zauważyć, iż wskaźniki dobrostanu maleją wraz z wiekiem młodzieży oraz w pewnych zakresach są wyższe u chłopców niż u dziewcząt.

Z przeprowadzonych badań wysnuć można także implikacje praktyczne, dotyczące dostosowania profilaktyki do wieku i płci adolescentów. Szczególną uwagą w zakresie planowania strategii wzmacniania dobrostanu psy-

${ }^{33}$ M. Zadworna-Cieślak, N. Ogińska-Bulik, Zachowania zdrowotne młodzieży - uwarunkowania podmiotowe i rodzinne, Warszawa 2011.

${ }^{34}$ E. Pisula, R. Sikora, Wiek i płeć a radzenie sobie ze stresem, s. 405-422.

35 H. Cheng, A. Furnham, Personality, peer relations, and self-confidence as a predictor of happiness and loneliness, Journal of Adolescence, 2002, 25, s. 327-339; E. Frydenberg, R. Lewis, Adolescent coping: The different ways in boys and girls cope, Journal of Adolescence, 1991, 14, s. 119-133. 
chicznego, w świetle prezentowanych danych, należy objąć młodzież starszą, w szczególności dziewczęta.

Prezentowane badania mają swoje ograniczenia. Ze względu na wielkość próby i jej niereprezentatywność oraz użycie niestandaryzowanego narzędzia pomiaru, należy zaprezentowane wyniki traktować jako pilotażowe. Przedstawione rezultaty wnoszą jednak ważne treści w obszar uwarunkowań dobrostanu młodzieży i dają początek dalszym poszukiwaniom empirycznym. Badania $\mathrm{w}$ zakresie tej problematyki mają bowiem istotne znaczenie praktyczne, wspomagając tworzenie programów profilaktycznych, zapobiegających angażowaniu się młodzieży w zachowania ryzykowne, promujących zdrowie psychiczne i wspierających prawidłowy rozwój.

\section{BIBLIOGRAFIA}

Casas F., Subjective social indicators and child and adolescent well-being, Child Indicators Research, 2011, 4(4).

Cheng H., Furnham A., Personality, peer relations, and self-confidence as a predictor of happiness and loneliness, Journal of Adolescence, 2002, 25.

Currie C., Zanotti C., Morgan A. i in., Social determinants of health and well-being among young people. Health Behaviour in School-Aged Children (HBSC) study: international report from the 2009/ 2010 survey, Copenhagen: World Health Organisation, 2012.

Czapiński J., Psychologia pozytywna, Wydawnictwo Naukowe PWN, Warszawa 2004.

Dziurowicz-Kozłowska A., Wokót pojęcia jakości życia, Psychologia Jakości Życia, 2002, 1(2).

Frydenberg E., Lewis R., Adolescent coping: The different ways in boys and girls cope, Journal of Adolescence, 1991, 14.

Gillham J.E., Hamilton J., Freres D.R., Patton K., Gallop R., Preventing depression among early adolescents in the primary care setting: A randomized controlled study of the Penn Resiliency Program, Journal of Abnormal Child Psychology, 2006, 34(2).

Gomez-Baya D., Mendoza R., Paino S., Gillham J.E., A two-year longitudinal study of gender differences in responses to positive affect and depressive symptoms during middle adolescence, Journal of Adolescence, 2017, 56.

Goswami H., Children's subjective well-being: socio-demographic characteristics and personality, Child Indicators Research, 2014, 7.

Havighurst R., Developmental tasks and education, Longman and Green, New York 1981.

Inchley J., Currie D., Young T., Samdal O., Torsheim T. i in., Growing up unequal: gender and socioeconomic differences in young people's health and well-being, Health Behaviour in School-aged Children (HBSC) study: international report from the 2013/2014 SURVEY, 2016, Źródło: http://www.euro.who.int/_data/assets/pdf_file/0003/303438/ HSBC-No.7-Growing-up-unequal-Full-Report.pdf?ua=1 [data dostępu: 19.06.17].

Kielar-Turska M., Rozwój człowieka w petnym cyklu życia, [w:] Psychologia. Podręcznik akademicki, red. J. Strelau, Gdańskie Wydawnictwo Psychologiczne, Gdańsk 2003.

King L.A., Eells J.E., Burton C.M., Pojęcie dobrego życia - w ujęciu szerokim $i$ wąskim, [w]: Psychologia pozytywna w praktyce, red. P.A. Linley, S. Joseph., Wydawnictwo Naukowe PWN, Warszawa 2007. 
Latos A., Kondycja psychiczna nastolatków. Raport z badań ankietowych przeprowadzonych w tarnowskich szkołach gimnazjalnych i ponadgimnazjalnych, 2014, Źródło: http:/ / edunet. tarnow.pl/res/edunet_portal/portalbu/aktual_2014/raport_kondycja_psychiczna_m_odziezy_2014__a._latos.pdf [data dostępu: 19.06.17].

Mazur J., Szkultecka-Dębek M., Dzielska A., Drozd M., Małkowska-Szkutnik A., What does the Cantril Ladder measure in adolescence?, Archives of Medical Science, 2016.

Mazur J. (red.), Zdrowie i zachowania zdrowotne młodzieży szkolnej w Polsce na tle wybranych uwarunkowań socjodemograficznych. Wyniki badań HBSC 2014, Instytut Matki i Dziecka, Warszawa 2015.

Obuchowska I., Adolescencja, [w:] Psychologia rozwoju człowieka. Charakterystyka okresów życia, red. B. Harwas-Napierała, J. Trempała, Wydawnictwo Naukowe PWN, Warszawa 2004.

Obuchowska I., Dorastanie - między moca a bezsilnościa, [w:] Zagrożenia okresu dorastania, red. Z. Izdebski, Wydawnictwo Uniwersytetu Zielonogórskiego, Zielona Góra 2012.

Oleszkowicz A., Senejko A., Dorastanie [w:] Psychologia rozwoju człowieka, red. J. Trempała, Wydawnictwo Naukowe PWN, Warszawa 2015.

Pisula E., Sikora R., Wiek i płeć a radzenie sobie ze stresem przez młodzież w wieku 12-17 lat, Przegląd Psychologiczny, 2008, 4.

Reivich K., Gillham J., Building Resilience in Youth: The Penn Resiliency Program, Communiqué, 2010, 38(6).

Ryff C.D., Happiness is everything, or is it? Explorations on the meaning of psychological well-being, Journal of Personality and Social Psychology, 1989, 57.

Seligman M., Petnia życia, Media Rodzina, Poznań 2012.

Sikora R., Pisula E., Przyczyny stresu i strategie radzenia sobie ze stresem u młodzieży w wieku 14-16 lat, Polskie Forum Psychologiczne, 2002, 2.

Strózik D., Strózik T., Szwarc K., The subjective well-being of school children. The first findings from the children's worlds study in Poland, Child Indicators Research, 2016, 9(1).

The WHOQOL Group, The World Health Organization Quality of Life Assessment (WHOQOL): Position Paper from the World Health Organization, Social Science and Medicine, 1995, 41(10).

Williams K., McGillicuddy-De Lisi A., Coping strategies in adolescents, Journal of Applied Developmental Psychology, 2000, 20.

Young J.F., Benas J.S., Schueler C.M., Gallop R., Gillham J.E., Mufson L., A randomized depression prevention trial comparing interpersonal psychotherapy - adolescent skills training to group counseling in schools, Prevention Science, 2016, 17(3).

Zadworna-Cieślak M., Sposoby i motywy zdobywania wiedzy przez uczniów szkót gimnazjalnych i ponadgimnazjalnych, [w:] Edukacja w zglobalizowanym świecie, red. V. Tanaś, W. Welskop, Wydawnictwo Naukowe Wyższej Szkoły Biznesu i Nauk o Zdrowiu, Łódź 2016.

Zadworna-Cieślak M., Ogińska-Bulik N., Zachowania zdrowotne młodzieży - uwarunkowania podmiotowe i rodzinne, Wydawnictwo Difin, Warszawa 2011.

Zawadzka D., Zadowolenie z życia, [w:] Zdrowie i zachowania zdrowotne młodzieży szkolnej w Polsce na tle wybranych uwarunkowań socjodemograficznych. Wyniki badań HBSC 2014, red. J. Mazur, Instytut Matki i Dziecka, Warszawa 2015.

\section{Źródła internetowe}

www.programyrekomendowane.pl 